\title{
Implementation of International Health Regulations in India
}

\author{
Tony Mathew M, Kannan Kunnathully
}

\begin{abstract}
The International Health Regulations (IHR) is a worldwide legitimate instrument appropriate to all WHO part nations and came into power in 2007. The goal of the IHR is to forestall global spread of malady by empowering part nations experience limit working for early identification, revealing and taking control measures against any general wellbeing crises of worldwide concern. The advancement of general wellbeing framework for gathering IHR standards should enable India to build up its reconnaissance, reaction and readiness limits which would improve results of its general wellbeing projects and help contain flare-ups. The present analysis was made through random sampling method where the survey was taken from common public, professionals, etc. The sample size in the present analysis is 1895 samples, the independent variable is in the analysis is gender and the dependent variables is reliable on the statement.The research tools used in the present paper such as cross tabulation, chi-square and case summary and graphical representation was also used to analyse the study. The study found that India faces difficulties in gathering its developing requirements for prepared disease transmission experts of a restorative foundation, entomologists, nourishment investigators and other pro staff occupied with general wellbeing observation exercises. It can be concluded that India ought to likewise not be content with gathering fundamental IHR standards but rather ought to endeavor to accomplish propelled abilities allowing it to help its neighboring nations with restricted general wellbeing foundation in gathering their IHR objectives.
\end{abstract}

KEYWORDS:India, WHO, International Health Regulations, surveillance, prevention

\section{INTRODUCTION}

The International Health Regulations (IHR) is a worldwide lawful instrument appropriate to all WHO part nations and came into power in 2007 (Agrawal).The guideline target of the IHR is to forestall the global spread of illness through an all inclusive system which empowers all nations in identifying, revealing and controlling potential 'general wellbeing dangers' running from limited episodes to pandemics(Sikka et al.).

The regulation of infections with pandemic potential is basic for ensuring the soundness of individuals while anticipating financial misfortunes comprehensively because of 'pointless impedance with global traffic and exchange' (Sikka et al.; "International Health Regulations"). The SARS (Severe intense respiratory disorder) pandemic in 2003 which uncovered the worldwide absence of readiness in averting the cross-country transmission of ailments in the time of high volume air travel prepared for change of the IHR for proceeded with importance in the 21st century(Hagen, "Port Health and International Health Regulations"). The IHR along these lines advanced from a constrained notice framework for just four sicknesses (smallpox, yellow fever, cholera and plague) and without whenever headed explicit instruments for joint effort among WHO and part states into a precise system for building up an organized worldwide reaction to "all occasions conceivably comprising a general wellbeing crisis of global concern (PHEIC)"(Bright).

The milestone arrangement in the IHR 2005 is the approval vested with the chief general of the WHO to announce and furthermore end the condition of a PHEIC which orders part states to carefully hold fast to an assigned calculation during every single speculated pandemic [12](Gostin and Katz). The states gatherings are liable to various commitments with respect to air terminals, ports and ground intersections in case of a PHIEC [4]. Part states were additionally required to reinforce their center capacities with respect to empowering and mounting viable reaction to pandemic like circumstances(Youde). The WHO has distinguished the accompanying eight center limits: (1) national enactment, approach, and financing, (2) coordination and national IHR point of convergence correspondences, (3) reconnaissance, (4) reaction, (5) readiness, (6) chance correspondence, (7) HR, and (8) research facility [5]. Besides, every signatory nation likewise requires to assign a national IHR point of convergence for "conveying nitty gritty general wellbeing data to WHO, including case definitions, research center outcomes, number of cases and passings and conditions influencing the spread of sickness"(Foster and Kumar) .

Be that as it may, the worldwide experience has demonstrated that most creating countries vacillated during the time spent creating center capacities with respect to identifying, evaluating, revealing and starting strides for containing PHIECs which constrained the WHO to expand the due date for gathering IHR center limits from 2012 to 2016 for 81 state gatherings (Fidler and Gostin).
Revised Manuscript Received on 14, October 2019.

Tony Mathew M, BBA., LL.B. (Hons.), Saveetha School of Law, Saveetha Institute of Medical and Technical Sciences (SIMATS), Chennai, Tamilnadu, India.

Kannan Kunnathully, Assistant Proffessor, Saveetha School of Law, Saveetha Institute of Medical and Technical Sciences (SIMATS), Chennai, Tamilnadu, India.(E-mail: kannankunnathully.ssl@saveetha.com) 


\section{Implementation of International Health Regulations in India}

\section{OBJECTIVES}

- To study about the methods and limits of implementing International Health Regulation in India.

- To study about India's preparedness in facing the epidemic of international concerns.

- To study the relationship between the IHR implementation and India's standing to face public health emergencies .

\section{RESEARCH METHODOLOGY AND METHOD}

The present paper was analysed through the non-doctrinal research methodology and empirical and descriptive method of research was used. The present analysis was made through random sampling method where the survey was taken from common public, professionals, etc. The sample size in the present analysis is 1895 samples, the independent variable is in the analysis is gender and the dependent variables is reliable on the statement. The research tools used in the present paper such as cross tabulation, chi-square and case summary and graphical representation was also used to analyse the study.

\section{LITERATURE REVIEW}

Agrawal, V. K.(2007) explains disappointment in gathering center limits and related postponement have been credited to absence of assets, deficient political will, political flimsiness, common war and fear mongering in India . Bright, Kristin(2012) says that the IHR are especially significant from the Indian perspective since India isn't just expected to agree to arrangements of the IHR yet in addition endeavor to take an administration position in empowering its neighboring nations in the South East Asian (SEAR) and also creating center limits in the study of disease transmission and reconnaissance exercises. Fidler, David P., and Lawrence O. Gostin(2017) pointed out that India because of its exceptional condition, geology and sociodemography is especially powerless against an assortment of developing and remerging contaminations with episodes of at any rate eight life forms detailed in the ongoing past . Foster, Andrew, and Naresh Kumar(2011) points that India imparts its fringes to 7 creating countries, some of which like Bangladesh and Myanmar are very permeable allowing ordinary yet undocumented and unregulated inflow of transients and creatures which can be a wellspring of infection like H5N1, India is especially powerless in light of the fact that reconnaissance limits of a portion of these neighboring nations is somewhat constrained. Hagen, D noted that as Bangladesh did not have an operational Japanese encephalitis reconnaissance program in spite of being an endemic nation for the illness. Pakistan is one of the nations as yet revealing polio cases. Under such conditions, it is fundamental for India to expand its epidemiological and observation limits equipped for creating early cautioning sign so as to decrease its helplessness against potential PHIECs emerging over its fringes(World Health Organization). Katz , Rebecca(2011) says that the appropriation of a "one wellbeing" technique could likewise help improve human, creature, and ecological well being and the reviews on Environmental Health as advancing inoculation of pooches could help control rabies while decreasing anti-infection use in creatures could lessen rise of antimicrobial obstruction. Li, Jian, and Alan Paisey.(2005) depicts the deficit of prepared disease transmission specialists in India which could be met by advancing consideration of short field epidemiological preparing programs inside course educational program of MD Community Medicine programs, understudies from unified wellbeing fields and science streams ought to be gives roads to preparing in general wellbeing disciplines particularly entomology and nourishment science. Youde, Jeremy (2010) researched the regulation of infections with pandemic potential is basic for ensuring the soundness of individuals while anticipating financial misfortunes comprehensively because of 'pointless impedance with global traffic and exchange', the SARS (Severe intense respiratory disorder) pandemic in 2003 which uncovered the worldwide absence of readiness in averting the crosscountry transmission of ailments in the time of high volume air travel prepared for change of the IHR for proceeded with importance in the 21 st century, the IHR along these lines advanced from a constrained notice framework for just four sicknesses (smallpox, yellow fever, cholera and plague) and without whenever headed explicit instruments for joint effort among WHO. Marais, Ben J., et al. states into a precise system for building up an organized worldwide reaction to "all occasions conceivably comprising a general wellbeing crisis of global concern (PHEIC), the milestone arrangement in the IHR 2005 is the approval vested with the chief general of the WHO to announce and furthermore end the condition of a PHEIC every signatory nation likewise requires to assign a national IHR point of convergence.

\section{TABLE AND ANALYSIS \& RESULTS}

\begin{tabular}{|c|c|c|c|c|c|}
\hline \multicolumn{6}{|c|}{ Gender } \\
\hline & & Frequency & Percent & Valid Percent & $\begin{array}{l}\text { Cumulativ } \\
\text { e Percent }\end{array}$ \\
\hline \multirow{3}{*}{$\begin{array}{l}\text { Val } \\
\text { id }\end{array}$} & Male & 1038 & 54.8 & 54.8 & 54.8 \\
\hline & Female & 857 & 45.2 & 45.2 & 100.0 \\
\hline & Total & 1895 & 100.0 & 100.0 & \\
\hline
\end{tabular}


Out of $100 \%$ of common people, $54.8 \%$ of people are male and has responded to the survey. The minority of people ie., $45.2 \%$ are female respondents. The gender gap is due to the effect of the place in which the survey took place where there were lot more of males than females.

\begin{tabular}{|l|l|l|l|l|l|}
\hline Working class & Frequency & $\begin{array}{l}\text { Perc } \\
\text { ent }\end{array}$ & $\begin{array}{l}\text { Valid } \\
\text { Percent }\end{array}$ & $\begin{array}{l}\text { Cumulative } \\
\text { Percent }\end{array}$ \\
\hline \multirow{3}{*}{ Valid } & Government Employee & 741 & 39.1 & 39.1 & 39.1 \\
\cline { 2 - 7 } & Private Employee & 625 & 33.0 & 33.0 & 72.1 \\
\cline { 2 - 7 } & Self Employed & 529 & 27.9 & 27.9 & 100.0 \\
\cline { 2 - 7 } & Total & 1895 & 100. & 100.0 & \\
\hline
\end{tabular}

Out of the total people who responded to the survey 39.1 $\%$ were Government employees, $33 \%$ of the respondents were Private employees and the remaining $27.9 \%$ were self employed.
Ho: There is no significant relationship between the IHR implementation and India's standing to face public health emergencies .

Ha:There is a significant relationship between the IHR implementation and India's standing to face public health emergencies .

Gender and The regulations are imposed $100 \%$ as by the WHO statistics

\begin{tabular}{|c|c|c|c|c|c|c|c|}
\hline & \multicolumn{5}{|c|}{ The regulations are imposed $100 \%$ as by the WHO statistics } & \multirow[b]{2}{*}{ Total } \\
\hline & & $\begin{array}{l}\text { Strongly } \\
\text { Disagree }\end{array}$ & Disagree & Neutral & Agree & $\begin{array}{l}\text { Strongly } \\
\text { Agree }\end{array}$ & \\
\hline \multirow{2}{*}{$\begin{array}{l}2 . \\
\text { Gender: }\end{array}$} & Male & 181 & 343 & 278 & 143 & 93 & 1038 \\
\hline & Female & 157 & 206 & 138 & 266 & 90 & 857 \\
\hline \multicolumn{2}{|l|}{ Total } & 338 & 549 & 416 & 409 & 183 & 1895 \\
\hline
\end{tabular}

From the table it can be noted that majority of the respondents $(338+549)$ have disagreed that the regulations are imposed $100 \%$ as by the WHO statistics. 416 respondents have given neutral answers to the question. (409+183) respondents have agreed to the statement that the regulations are imposed $100 \%$ as by the WHO statistics. The gender difference here is that the females have agreed more than men as that the regulations are imposed $100 \%$ as by the WHO statistics.

As the Pearson Chi-square value is less than 0.05 the null hypothesis is rejected.

4.Chi-Square Tests
\begin{tabular}{|l|l|l|l|}
\hline & & & Asymptotic \\
& Value & df & $\begin{array}{l}\text { Significance } \\
\text { sided })\end{array}$ \\
\hline Pearson Chi-Square & $103.705^{\mathrm{a}}$ & 4 & .000 \\
Likelihood Ratio & 104.609 & 4 & .000 \\
Linear-by-Linear Association & 23.056 & 1 & .000 \\
N of Valid Cases & 1895 & & \\
\hline
\end{tabular}

a. 0 cells $(0.0 \%)$ have expected count less than 5 . The minimum expected count is 82.76 . 


\section{Implementation of International Health Regulations in India}

Working class and The regulations are imposed $100 \%$ as by the WHO statistics

\begin{tabular}{|c|c|c|c|c|c|c|c|}
\hline & \multicolumn{5}{|c|}{ The regulations are imposed $100 \%$ as by the WHO statistics } & \multirow[b]{2}{*}{$\begin{array}{l}\text { Tot } \\
\text { al }\end{array}$} \\
\hline & & $\begin{array}{c}\text { Strongl } \\
\text { y Disagree }\end{array}$ & $\begin{array}{l}\text { Disagre } \\
\mathrm{e}\end{array}$ & Neutral & Agree & $\begin{array}{l}\text { Strongly } \\
\text { Agree }\end{array}$ & \\
\hline \multirow[t]{3}{*}{$\begin{array}{l}\text { Working } \\
\text { class }\end{array}$} & $\begin{array}{l}\text { Government } \\
\text { Employee }\end{array}$ & 96 & 244 & 213 & 143 & 45 & 741 \\
\hline & $\begin{array}{r}\text { Private } \\
\text { Employee }\end{array}$ & 186 & 166 & 90 & 103 & 80 & 625 \\
\hline & Self Employed & 56 & 139 & 113 & 163 & 58 & 529 \\
\hline \multicolumn{2}{|l|}{ Total } & 338 & 549 & 416 & 409 & 183 & $\begin{array}{r}189 \\
5\end{array}$ \\
\hline
\end{tabular}

From the table it can be noted that majority of the respondents $(338+549)$ have disagreed that the regulations are imposed $100 \%$ as by the WHO statistics. 416 respondents have given neutral answers to the question. (409+183) respondents have agreed to the statement that the regulations are imposed $100 \%$ as by the WHO statistics. The working class difference is that private employers has strongly agreed than other respondents. Majority of government employees have taken a neutral stand and the self employed people have agreed more than the other respondents.

As the Pearson Chi-square value is less than 0.05 the null hypothesis is rejected.

\section{DISCUSSIONS}

The IHR gives India special open doors for improving the wellbeing status of its own populace and add to improvement of worldwide wellbeing yet in addition sets difficulties which must be survived. India has weakness lists with just 1 specialist for every 1800 and only 1 emergency clinic bed for every 1000 populace(Das). The IHR in this manner furnish India with an extra impetus for wellbeing framework reinforcing and limit building endeavors which likewise diminish the danger of overstretching restricted general wellbeing frameworks and license their reasonable advancement( $\mathrm{Li}$ and Paisey). India ought to likewise consider duty of assets to meet IHR prerequisites in its neighboring nations particularly those with which it shares its fringes any place it is doable by arrangement of specialized aptitude, preparing and material assets like drugs and bed nets. Fortifying of reconnaissance frameworks in India would help improve yields identified with a few national wellbeing programs for control of HIV-AIDS, Vector borne illnesses, etc.

Given the various parameters and the complex collection of legislations, the more probable way of setting up a comprehensive and effective SOP would be by adopting a problem-solution approach for every given circumstance and weaving the SOP into a vast resource-mobilizing machinery that would be equally effective in handling anything, from a regional outbreak to a national emergency.

\section{SUGGESTION AND RECOMMENDATIONS}

Since wellbeing is a state subject in India, the legislature of India has arranged setting up of NCDC branches in the states through a decentralized procedure so as to upgrade HR for fortifying limit with regards to episode examination, counteractive action and control of general wellbeing crises [13]. Existing activities incorporate limit working in the study of disease transmission through standard Field Epidemiology Training Programs both for Indian and WHO supported medicinal alumni from nations in the SEAR district [14]. An Epidemic Intelligence Service (EIS) program keep running in a joint effort with the CDC, Atlanta is in activity since 2012 with the target of creating exceedingly talented disease transmission experts every year [15]. All things considered, these measures are as yet lacking since growing auspicious 'Reaction' (Core limit 4) to any associated episode requires the situating with a Rapid Response Team in each area of the nation. At last, India can be a significant accomplice in improving worldwide security and must endeavor to be a model state in actualizing the IHR at the propelled levels and turning into a key player in protecting worldwide wellbeing.

\section{CONCLUSION}

The study has identified the laws and the ministries that govern the laws. It is apparent from the study that a number of relevant legal provisions required to control and contain an outbreak have been enacted and are in force. However, there are gaps in harmonizing the actions of the existing systems including the nascent system being developed by NCDC along with all the resources - especially for containment and mitigation of a situation capable of being declared an outbreak as well as an existing outbreak. Consequently, the administration of India's Integrated Disease Surveillance program commands a prepared disease transmission specialist to be enlisted in every one of the 640 regions of the nation which isn't achievable since the quantity of officially prepared disease transmission specialists is still low in India. India still has a long way to go before all diagnostic laboratories are certified or accredited according to international standards, or to national standards adapted from international standards as recommended by the WHO. 
There is an need to develop SOP invoking relevant legislation and having authorities thereunder in place, by the relevant participating ministries, so that all resources can be mobilized immediately in the event of an imminent or a full blown outbreak.

\section{REFERENCES}

1 Agrawal, V. K. "Pandemic Response and International Health Regulations.” Medical Journal Armed Forces India, vol. 63, no. 4, 2007, pp. 366-67, doi:10.1016/s0377-1237(07)80018-9.

2 Basker, Mona M. "Adolescent Health in Asia: Insights from India." International Journal of Adolescent Medicine and Health, vol. 28, no. 3, 2016, doi:10.1515/ijamh-2016-5017.

3 Bright, Kristin. "International Health Regulations." Encyclopedia of Immigrant Health, 2012, pp. 930-33, doi:10.1007/978-1-4419-5659$0 \_416$.

4 Das, Shankar. "The Health Care System in India." Health Care Systems in Developing Countries in Asia, 2017, pp. 149-82, doi:10.4324/9781315586403-7.

$5 \quad$ Fidler, David P., and Lawrence O. Gostin. "The New International Health Regulations: An Historic Development for International Law and Public Health." Global Health, 2017, pp. 489-98, doi:10.4324/9781315254227-36.

6 Foster, Andrew, and Naresh Kumar. "Health Effects of Air Quality Regulations in Delhi, India." Atmospheric Environment, vol. 45, no. 9, 2011, pp. 1675-83, doi:10.1016/j.atmosenv.2011.01.005.

7 Gostin, Lawrence O., and Rebecca Katz. "The International Health Regulations: The Governing Framework for Global Health Security." The Milbank Quarterly, vol. 94, no. 2, 2016, pp. 264-313, doi:10.1111/1468-0009.12186.

8 Hagen, D. "Case Study 1: Port Health and International Health Regulations." Introduction to Pandemic Influenza, pp. 194-201, doi:10.1079/9781845936259.0194.

9 ---. "Port Health and International Health Regulations." Pandemic Influenza, pp. 164-72, doi:10.1079/9781845938567.0164

10 "International Health Regulations." SpringerReference, doi:10.1007/springerreference_225240.

11 Jones, Dilwyn T. "International Health Regulations." Handbook of Nautical Medicine, 1984, pp. 310-15, doi:10.1007/978-3-642-694158_35.

12 Katz, Rebecca. "International Health Regulations." Encyclopedia of Bioterrorism Defense, 2011, doi:10.1002/0471686786.ebd0162.

13 Krishnamoorthy, Yuvaraj, et al. "Emerging Public Health Threat of EWaste Management: Global and Indian Perspective." Reviews on Environmental Health, vol. 33, no. 4, Dec. 2018, pp. 321-29.

$14 \mathrm{Li}, \mathrm{Jian}$, and Alan Paisey. "Influential Regulations." International Transfer Pricing in Asia Pacific, 2005, pp. 28-49, doi:10.1057/9780230511606_3.

15 Luz, G. A. "Noise Management: International Regulations." Encyclopedia of Environmental Health, 2011, pp. 164-73, doi:10.1016/b978-0-444-52272-6.00258-0.

16 Marais, Ben J., et al. "Improving Emergency Preparedness and Response in the Asia-Pacific.” BMJ Global Health, vol. 4, no. 1, Jan. 2019, p. e001271.

17 Sikka, Veronica, et al. "The 2017 International Joint Working Group White Paper by INDUSEM, the Emergency Medicine Association and the Academic College of Emergency Experts on Establishing Standardized Regulations, Operational Mechanisms, and Accreditation Pathways for Education and Care Provided by the Prehospital Emergency Medical Service Systems in India." Journal of Emergencies, Trauma, and Shock, vol. 10, no. 3, July 2017, pp. 15461.

18 Team, Eurosurveillance Editorial, and Eurosurveillance editorial team. "International Health Regulations." Weekly Releases (19972007), vol. 2, no. 7, 1998, doi:10.2807/esw.02.07.01259-en.

19 World Health Organization. International Health Regulations (2005). World Health Organization, 2008.

20 Youde, Jeremy. "The International Health Regulations.” Biopolitical Surveillance and Public Health in International Politics, 2010, pp 147-75, doi:10.1057/9780230104785_7. 